\title{
Prikupljanje građe i oblikovanje muzejskih zbirki kao doprinos razumijevanju razvoja povijesti umjetnosti i poznavanju kulturne baštine - primjer Muzeja Slavonije
}

Šimičić, Andreja

Source / Izvornik: Institucije povijesti umjetnosti : zbornik 4. kongresa hrvatskih povjesničara umjetnosti, 2019, 167 - 171

Conference paper / Rad u zborniku

Publication status / Verzija rada: Published version / Objavljena verzija rada (izdavačev PDF)

https://doi.org/10.31664/z4khpu.23

Permanent link / Trajna poveznica: https://urn.nsk.hr/urn:nbn:hr:254:329289

Rights / Prava: Attribution 4.0 International/Imenovanje 4.0 međunarodna

Download date / Datum preuzimanja: 2023-04-26

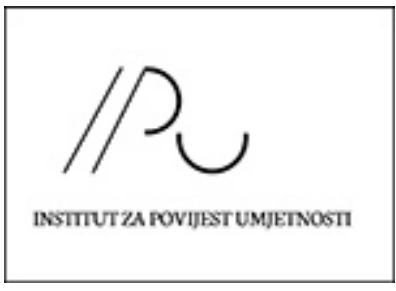

Repository / Repozitorij:

PODEST - Institute of Art History Repository

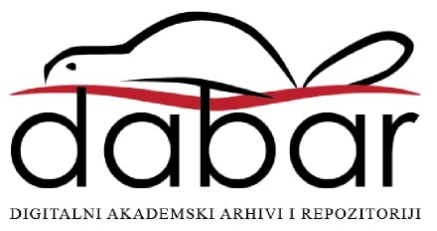




\section{Prikupljanje građe i oblikovanje muzejskih zbirki kao doprinos razumijevanju razvoja povijesti umjetnosti i poznavanju kulturne baštine-primjer Muzeja Slavonije}

\section{Uvod s kratkim pregledom dosadašnjih istraživanja}

Za razumijevanje povijesti kulturne baštine muzeji su, sa svojom građom sistematiziranom u zbirke, neiscrpni materijalni izvor informacija i znanja. Kako sami muzealci, tako i znanstvenici zaposleni u drugim institucijama, u stručnom i znanstvenom radu posežu za muzejskim predmetom i muzejskom zbirkom kao nositeljima znanstvenih i kulturnih podataka. No muzejski predmet, prikupljanje građe te njihovo oblikovanje u zbirke također su predmet proučavanja i teoretskih promišljanja. Ovaj rad pokušaj je spoznavanja utjecaja prikupljanja građe i njezina sistematiziranja u muzejske zbirke na razumijevanje razvoja povijesti umjetnosti. Preko odgovora na pitanja kako odgovorno prikupljati predmete za muzejske zbirke, čuvati ih i komunicirati njihova značenja, pokušat će se ponovno osvijestiti teza da je ozbiljno proučavanje kulturne i prirodne baštine u muzejima moguće tek međusobnim povezivanjem znanja i metoda muzeologije i temeljne znanstvene discipline; za kustose-povjesničare umjetnosti to je povijest umjetnosti. ${ }^{1}$ Muzej Slavonije, sa svojom dugom i bogatom poviješću, primjer je te prakse.

Svaki pokušaj spoznavanja povijesti muzeja nužno počinje pričom o sabiranju, istraživanjem povijesti kolekcionara i njihovih zbirki. Brojni su radovi istraživača i znanstvenika osvijestili povijest sabiranja kao izvora za povijest muzeja u Hrvatskoj; spomenimo se na početku vrijedne i važne publikacije muzeologinje Žarke Vujić. ${ }^{2}$ Prikaz sabiranja te oblikovanja zbirki u kontekstu privatnog kolekcionarstva, odnosno prije osnivanja prvih muzeja, objavila je r958. godine Verena Han. ${ }^{3}$ Muzejskim zbirkama u kontekstu izvora za znanstvena istraživanja bavila se Branka Šulc. ${ }^{4}$ Povijest muzeja kao institucije, muzejski predmet, muzejske zbirke te odnos muzeologije i povijesti umjetnosti proučavao je Ivo Maroević, utemeljitelj Katedre za muzeologiju Filozofskog fakulteta Sveučilišta u Zagrebu. ${ }^{5}$ Povijest sabiranja te povijest muzeja u Hrvatskoj, proučavanje oblikovanja zbirki te odnos muzeologije i povijesti umjetnosti

\section{Andreja Šimičić}

Muzej Slavonije, Osijek andreja.simicic@mso.hr

https://orcid.org/oooo-0oo2-6250-2052
I IVO MAROEvić, Uvod u muzeologiju, Zagreb, Zavod za informacijske studije Odsjeka za informacijske znanosti, Filozofski fakultet Sveučilišta u Zagrebu, I993.

2 ŽARKA VUJIĆ, Izvori muzeja u Hrvatskoj: Including a comprehensive summary in English, Zagreb, Kontura Art magazin, 2007.

3 VERENA HAN, Razvoj zbirki i muzeja od XIII. do XIX vijeka na teritoriju Jugoslavije, u: Tkalčićev zbornik, 2 (I958.), 297-316.

4 BRANKA ŠULC, Muzejske zbirke kao izvor naučnih informacija za povijest svoga kraja, u: Muzeologija, I9 (I975.), II4-I22.

5 Uz ranije spomenutu knjigu IVO MAROEVIĆ (bilj. I), u kontekstu proučavanja muzejskog predmeta važno je spomenuti i: IVO MAROEVIĆ, Muzejski predmet kao povijesni izvor i dokument, $\mathrm{u}$ : Informatica museologica, 36 (I-2), (2005) ), 54-57. 
u središtu su zanimanja i proučavanja Žarke Vujić. ${ }^{6}$ Muzeologinja i teoretičarka materijalne kulture sa Sveučilišta u Leicesteru Susan Pearce objavila je značajne radove o muzejskim predmetima, zbirkama i sabiranju na europskom tlu, a odnosom povijesti umjetnosti i muzeologije bavi se povjesničar umjetnosti Donald Preziosi sa Sveučilištu u Kaliforniji. Važno je spomenuti i časopis Journal of the History of Collections, koji izdaje Oxford University Press i koji se bavi temama prikupljanja, te Center for the History of Collecting, osnovan 2007. godine kao dio Frick Art Reference Library iz New Yorka, a u svrhu poticanja proučavanja oblikovanja javnih i privatnih zbirki lijepih umjetnosti i primijenjene umjetnosti, kako u Sjedinjenim Američkim Državama tako i u Europi. ${ }^{8}$

\section{Prikupljanje građe i oblikovanje muzejskih zbirki}

Prikupljanjem građe oblikuju se muzejske zbirke, a muzejski poslovi međusobno su povezani: s jedne strane prikupljanjem povećavamo zbirku, a istovremeno projekcija zbirke planom popunjavanja upućuje na predmete koji nedostaju u njoj. Sustavno prikupljanje građe zahtijeva izradu dobrog i stručnog plana popunjavanja nedostajućim reprezentativnim predmetima (plan prikupljanja, politika skupljanja ili pisana načela sabiranja), za što je nužno dobro poznavanje postojeće zbirke. ${ }^{9}$ Popunjavanje fundusa određeno je poslanjem zbirke, koje je temeljeno na odrednicama poslanja muzeja. Za izradu plana prikupljanja građe, osim toga, primjenjuje se znanje iz temeljne znanstvene discipline kustosa: za umjetničke zbirke te za zbirke umjetničkog obrta to su znanja povijesti umjetnosti.

Prikupljanje definira zbirku kao skup odabranih predmeta. Predmet postaje muzejski predmet zbog svog značenja, zbog toga što je primjer koji nosi određenu estetsku, povijesnu, simboličnu vrijednost. Muzejski predmeti i zbirke objašnjavaju i ilustriraju razvoj stilova, tehnike i tehnologije, kretanje međusobnih utjecaja autora i stilova, mijenu stavova i vrijednosti, izvore pribavljanja predmeta, a umjetničke zbirke također i odnos ljudi prema lijepom.

Procesom muzealizacije predmet je izdvojen iz prirodnog konteksta, prve stvarnosti, njegov stvarni identitet ostaje neka vrsta nultog kriterija. ${ }^{10}$ Razlikujemo tri, odnosno pet identiteta (slojeva istraživanja) predmeta: idejni, koji nastaje prije same materijalizacije predmeta, stvarni ili identitet u trenutku nastanka predmeta te onaj zbiljski, identitet predmeta u trenutku našeg kontakta s njime. Osim navedenih, I. Maroević uvodi pojam povijesni ili identitet trajanja, koji obuhvaća i identitet koji nastaje između nastanka predmeta i kontakta s njim. P. van Mensch taj identitet trajanja razdvaja na strukturalni (identitet materijalnosti predmeta) i funkcionalni (identitet namjene). Predmet je dijelom zbirke postao upravo zbog tog svog identiteta u trenutku nastanka. Stavljajući ga u novi kontekst, kontekst muzejske zbirke, zanimanje je prošireno na sve navedene identitete. Taj novi kontekst daje nam širu sliku povijesnog i povijesno-umjetničkog značaja predmeta. Predmeti
6 Osim već citirane knjige ŽARKA vUJIĆ (bilj. 2), važni su radovi: ŽARKA vUJIĆ, Sabirem dakle jesam: Levin Horvath, u: Muzeologija, 32 (I995.), 23-32; ŽARKA vUJIĆ, Kvaliteta i politika sabiranja, u: Informatica museologica, 33 (3-4), (2002.), I65-I37; ŽARKA VUJIĆ, Odnos muzeologije prema povijesti umjetnosti, u: Zbornik I. kongresa hrvatskih povjesničara umjetnosti, (ur.) Milan Pelc, Zagreb, Institut za povijest umjetnosti, 2004., 349-352.

7 SUSAN M. PEARCE, Collecting reconsidered, u: Interpreting Objects and Collections, (ur.) Susan M. Pearce, London and New York, I93-204; web dostupno izdanje objavljeno $u$ : Taylor \& Francis e-Library, 2003.; DONALD PREZIOSI, Historija umetnosti i muzeologija: Pretvoriti vidljivo u čitljivo, u: Vodič kroz muzejske studije, (ur.) Sharon MacDonald, Beograd, Clio, Narodni muzej, 2oI4. U Vodiču kroz muzejske studije prevedeno je još nekoliko radova zanimljivih za temu oblikovanja zbirki.

8 The Frick Collection. http://www.frick.org/research/ center (posjećeno 8. prosinca 20I6.).

9 Pogledati: KREŠIMIR BAŠIĆ. Pisana izjava: Politika skupljanja, u: Informatica museologica, 27 (I-2), (I996.), I4. Čitav je broj 27 (I-2) posvećen prikupljanju muzejske građe. Pogledati također tekst Žarke Vujić s Godišnje konferencije Komiteta za regionalne muzeje ICR/ICOM-a, Hrvatska, 2002. godine, objavljen u časopisu Informatica museologica. ŽARKA VUJIĆ (bilj. 6, 2002.), I37.

Io Na Prvom kongresu hrvatskih povjesničara umjetnosti, kao i u radu objavljenu u Zborniku,Žarka Vujić više je govorila o identitetima predmeta, dotičući se radova P. van Menscha i I. Maroevića. ŽARKA VUJIĆ (bilj. 6, 2004.), 350; IVO MAROEVIĆ (bilj. I), II6-II7. 
čine cjelinu koja postaje izvor informacija, kulturoloških i znanstvenih, za temeljnu znanstvenu disciplinu kustosa, voditelja zbirke. Muzeološki pristup često navodi znanstvenike na novi trag i nove putove do izvora, osvještavanja šireg konteksta značenja predmeta, shvaćanja i osvještavanja zbiljskog identiteta predmeta. Usustavljen u zbirku, predmet nam pruža nova čitanja, dok zbirka rekontekstualizira predmet. ${ }^{11}$ Budući da svaki predmet u zbirci određuje zbirku, važno je odrediti postoje li pravila definiranja muzejske zbirke.

Zakonskom regulativom Republike Hrvatske muzejska građa i muzejska zbirka definirane su Pravilnikom o stručnim $i$ tehničkim standardima za odredivanje urste muzeja, za njihou rad, te za smještaj muzejske građe i muzejske dokumentacije objavljenim u Narodnim novinama Io. ožujka 20o6. godine. ${ }^{12}$ Prema čl. I9 Pravilnika, zbirku može odrediti materijal predmeta, razdoblje nastanka, stilska obilježja, autor, škola, pokret, tema, osoba, događaj, teritorij, medij, tehnika i tehnologija, određena znanstvena disciplina, specifična ljudska djelatnost. Dakle, za organiziranje muzejske građe po zbirkama nisu utvrđena posebna formalna pravila, zbirke se ustrojavaju prema jednom ili čak i više obilježja navedenih u članku Pravilnika. Svaka ih muzejska ustanova određuje prema svom fundusu i svojoj tradiciji.

Poput niza drugih muzeja osnovanih koncem Ig. stoljeća, Muzej Slavonije svoje postojanje duguje osječkim sabirateljima. Franjo Sedlaković i Franjo Karlo Nuber nezaobilazna su imena pri svakom spomenu prvih godina postojanja Muzeja. ${ }^{13}$ Osnovan I877. godine kao Muzej Slobodnoga i kraljevskog grada Osijeka, danas je jedan od najvećih muzeja u Republici Hrvatskoj, nacionalni muzej općeg tipa, koji prikuplja građu arheološkog, prirodoslovnog, povijesnog, kulturnopovijesnog, tehničkog, etnološkog i umjetničkog značaja. ${ }^{14}$ Građa se čuva u osam stručnih muzejskih odjela, usustavljena u više od i6o zbirki. Kako i dopušta navedeni Pravilnik, zbirke su određene prema različitim kriterijima-od materijala, lokaliteta, tema, osobe kolekcionara... ${ }^{15}$

Strateškim planom Muzeja Slavonije određen je teritorijalni kontekst, tj. Muzej „prikuplja, skrbi, proučava i komunicira baštinu istočne Hrvatske, s posebnim naglaskom na Osječkobaranjsku županiju i grad Osijek", ${ }^{16}$ pa u njegove zbirke ulaze predmeti nastali ili korišteni na osječkom ili slavonsko-baranjskom području, ili ih je stvorio autor koji je rođen ili je dio života proveo na tom području.

U Muzeju Slavonije povjesničari umjetnosti tradicionalno su zaposleni u Odjelu umjetničkog obrta, u kojem se čuvaju predmeti umjetničkog obrta i primijenjene umjetnosti, umjetničke slike te predmeti svakodnevnog života, sistematizirani $\mathrm{u}$ devetnaest zbirki. Iako je navedena građa prikupljana od samih početaka Muzeja, Odjel umjetničkog obrta osnovan je I95I. godine, otvaranjem stalnog postava stilskog namještaja uz dekorativne predmete i umjetničke slike. Kako se fundus povećavao, tako su se oblikovale zbirke Odjela: od Odjela umjetnog obrta, kako ga je nazvala dugogodišnja ravnateljica Danica Pinterović, preko devet zbirki koje je vodila viša kustosica Ida Horvat, prva povjesničarka umjetnosti Muzeja
II ŠERON MAKDONALD [SHARON MACDONALD], Kolekcionarstvo, u: Vodič kroz muzejske studije, (ur.) Sharon MacDonald, Beograd, Clio, Narodni muzej, 20I4., I25. I2 Pravilnik o stručnim i tehničkim standardima za određivanje vrste muzeja, za njihov rad, te za smještaj muzejske građe i muzejske dokumentacije, 2006. URL: http://narodne-novine.nn.hr/clanci/sluzbeni/2oo6_o3-30_7I8.html (posjećeno 5. prosinca 20I6.).

I3 O osnivanju Muzeja Slavonije pogledati: HERMINE GÖRICKE-LUKIĆ, Numizmatičari Franjo Ladislav Sedlaković i Karlo Franjo Nuber-osnivači osječkoga Muzeja, u: Osnivači i prvi kustosi muzeja u Hrvatskoj: stručni skup u Osijeku II.-I2. prosinca I997., (ur.) Mladen Radić, Osijek, I999., 9I-Io3, te MLADEN RADIĆ. Muzej Slavonije u Osijeku I877.-I997. u: Osnivači i prvi kustosi muzeja u Hrvatskoj: Stručni skup u Osijeku, II.-I2. prosinca I997, (ur.) Mladen Radić, Osijek, ı999., I04-II6.

I4 Nakon održanog izlaganja na 4. kongresu hrvatskih povjesničara umjetnosti i predaje pisanoga rada došlo je do izdvajanja Arheološkog muzeja iz Muzeja Slavonije. Vlada RH je na sjednici održanoj I. prosinca 20I7. godine donijela Uredbu o osnivanju Arheološkog muzeja Osijek. Uredbom se sva muzejska građa i muzejska dokumentacija, među ostalim, koja je služila za obavljanje poslova iz područja arheologije izuzima iz Muzeja Slavonije. Tom Uredbom Muzej Slavonije više ne prikuplja građu arheološkoga značaja. Ipak, i danas je Muzej Slavonije najveći muzej općega tipa u RH.

I5 U Registru kulturnih dobara Ministarstva kulture pod oznakom $\mathrm{Z}-3808$, kao muzejska građa Muzeja Slavonije upisane su primjerice Zbirka keramike, Zbirka latenskih nalaza s nekropole Osijek-Ciglana-Zeleno polje, Zbirka glazbenih instrumenata,Zbirka numizmatike Rudolfa Normanna grofa valpovačkog i druge. http://www.min-kulture. $\mathrm{hr} /$ default.aspx?id=62 I $2 \& \mathrm{kdId}=250874590 \quad$ (posjećeno I2. prosinca 2016.).

I6 Strateški plan Muzeja Slavonije: (20I6.-2oı8.), Osijek, 20I5. Odjel za administrativne i financijske poslove Muzeja Slavonije. 
Slavonije, do današnje strukture od devetnaest zbirki, kako je građu usustavila viša kustosica Radmila Biondić. Odjel je sa svojom građom dobar primjer kako muzejska zbirka nije ni zatvorena ni statična cjelina. Vjerojatno nam i nudi odgovor na pitanje zašto ne postoji točno određenje ni definicija muzejske zbirke, odnosno pravilo sistematiziranja građe u zbirke. Zbirke Odjela umjetničkog obrta popunjavaju se predmetima koji nose umjetničke i likovne osobine vrijedne i važne za prostor Slavonije, predmetima koji omogućuju spoznavanje razvoja umjetničkog obrta i likovne umjetnosti Osijeka i Slavonije, osvještavaju postojanje kolekcionara. U počecima postojanja Odjela, iako promišljani kroz zbirke, predmeti nisu bili posebno usustavljeni u zbirke. Postojala je svijest o zbirkama satova, namještaja, keramike, stakla, no još I982. godine, pri tadašnjem Ministarstvu kulture, kao kulturno dobro zaštićena je Zbirka umjetničkog obrta (oznaka: ROS-II2). Iz Zbirke umjetničkog obrta oblikuju se Zbirka namještaja, Zbirka satova, Zbirka keramike, Zbirka stakla, Zbirka metala, Zbirka tekstila, odjeće i modnog pribora, Zbirka sakralnih predmeta i Zbirka varia. Predmeti su bili raspoređeni u zbirke uglavnom prema vrsti materijala, da bi, s razvojem muzeološke misli, proizišla nova sistematizacija, koja se zadržala do danas. ${ }^{17}$ Zadržane su „stare” zbirke, no tamo gdje je bilo moguće predmeti su, prema određenom kriteriju, uglavnom tematskom, izlučeni i grupirani u nove zbirke.

Jedan je od primjera današnja Zbirka rasvjetnih tijela, nastala izlučivanjem predmeta iz nekoliko zbirki Odjela i njihovim spajanjem u novu cjelinu. Materijalom raznovrsni predmeti u vezi s rasvjetom bili su male cjeline unutar Zbirke namještaja, Zbirke keramike, Zbirke metala. S osnivanjem Zbirke rasvjetnih tijela nekoliko pozlaćenih drvenih svijećnjaka izrađenih u rokoko stilu, klasicističkih lustera i zidnih svijećnjaka te secesijskih svijećnjaka istaknuli su se unutar zbirke, dok su u velikim cjelinama ostali u sjeni većih komada namještaja, talijanske majolike i fajanse, kositrenih baroknih tanjura...

Otvorenost zbirki novim predmetima ne zaustavlja se ni u zbirkama koje se čine zatvorenim cjelinama, čak i kad ih čine predmeti koji se više ne izrađuju. Primjerice Zbirka plesnih rasporeda nije nužno zatvorena zbirka, već je označavamo zbirkom u nastajanju jer, iako danas više nema balova ni plesova na kojima bi dame upisivale plesače i plesove, još je moguće u skrivenoj ladici pronaći taj predmet koji izradom i korištenjem pripada prošlosti. ${ }^{18}$

Današnji muzejski informatički sustav omogućuje stvaranje neke vrste virtualnih zbirki: bez obzira na zbirku ili odjel u kojoj se predmet nalazi moguće je objedinjavanje predmeta u zajedničku zbirku. U računalnom programu za inventarizaciju muzejskih zbirki M++, kojim se koristi Muzej Slavonije, u podobrascu Povijest osnovnog obrasca nalazi se polje Tematske cjeline, gdje je moguće stvaranje cjelina odnosno zbirki. ${ }^{19}$ U muzeju općeg tipa, kakav je Muzej Slavonije, takvo dodatno stvaranje zbirki s predmetima iz različitih odjela povećava broj i kvalitetu informacija koje odašilje muzejski predmet.
I7 Odjel umjetničkog obrta danas je sistematiziran u devetnaest zbirki: Zbirka namještaja, Zbirka satova, Zbirka keramike, Zbirka stakla, Zbirka metala, Zbirka slika i okvira, Zbirka sakralnih predmeta, Zbirka odjeće, Zbirka modnog pribora, Zbirka ambalaže i reklamnih predmeta, Zbirka dekorativnih predmeta, Zbirka glazbenih instrumenata, Zbirka plesnih rasporeda, spomenara, straničnika i sl., Zbirka rasvjetnih tijela, Zbirka igračaka, Zbirka nakita, Zbirka osobnih predmeta, Zbirka kućanskog tekstila i Zbirka kućanskih predmeta.

I8 Muzej Slavonije u listopadu 2oı6. godine svoju je Zbirku plesnih rasporeda, spomenara, straničnika i sl. popunio vrijednim darom nekoliko plesnih rasporeda s kraja devetnaestog i početka dvadesetog stoljeća.

I9 Stvaranje takvih zbirki osobito je korisno u slučaju velikih donacija koje predmete sistematiziraju u različite odjele Muzeja, primjerice Donacija Branka Mihaljevića ili Donacija Julija Njikoša. 


\section{Zaključno}

Odgovorno prikupljanje predmeta i njihovo stručno i sistematizirano okupljanje u muzejske zbirke prvi je korak u razumijevanju i širenju novih spoznaja razvoja temeljne struke kustosa, voditelja zbirke. Kustos, povjesničar umjetnosti, muzejski predmet identificira, stilskom analizom stavlja u kontekst suvremenih umjetničkih kretanja te ga vrednuje i interpretira. Rezultati i spoznaje stručnog i znanstvenog istraživanja prikazuju se izložbom i katalogom uz izložbu. Svaki stručni i znanstveni rad u kojem je publiciran muzejski predmet, objavljena pojedina zbirka, predavanjem izložena, odnosno izložbom obrađena tema kamenčić su u mozaiku spoznavanja hrvatske kulturne baštine, novi prilog razumijevanju hrvatske povijesti umjetnosti. Muzejska građa tada postaje vidljiva stručnoj javnosti, kako kolegama muzeolozima tako i povjesničarima umjetnosti, te postaje vidljivi sastavni dio kulturne baštine.

Prva stručna publikacija o stilskom razvoju namještaja tijekom razdoblja u Hrvatskoj rezultat je stručnog i znanstvenog rada vezana uz otvaranje muzejskog stalnog postava Odjela umjetničkog obrta Muzeja Slavonije. Povijest namještaja: ilustrirana primjerima Muzeja Slavonije, koju je I952. godine napisala Danica Pinterović, nastala je kao sinteza proučavanja stručne literature o stilovima namještaja, primjeni tih spoznaja na predmete $u$ Muzeju te objavi rezultata istraživanja u obliku kataloga izložbe, koji ujedno donosi nove spoznaje o izradi i sabiranju predmeta umjetničkog obrta Osijeka i okolice. ${ }^{20}$ Istodobno osnovni je rad za dalja proučavanja razvoja primijenjene umjetnosti, napose izrade stilskog namještaja. ${ }^{21}$

$\mathrm{Na}$ kraju valja istaknuti da je jedno od najvažnijih poslanja i povjesničara umjetnosti i kustosa istraživanje i čuvanje hrvatske kulturne baštine te pravilna valorizacija predmeta i zbirki $\mathrm{u}$ nacionalnom i internacionalnom kontekstu, kako u doba nastanka, tako i u današnjem kontekstu, kao rezultat međusobnog utjecaja istraživanja obiju znanstvenih disciplina.

\section{(a) (1)}

Prikupljanje građe i oblikovanje muzejskih zbirki kao doprinos razumijevanju razvoja povijesti umjetnosti i poznavanju kulturne baštine-primjer Muzeja Slavonije / Andreja Šimičić / CC BY / 4.o

DOI: https://doi.org/Io.3I664/z4khpu.23
20 DANICA PINTEROVIĆ, Povijest namještaja: ilustrirana primjerima Muzeja Slavonije, Osijek, Muzej Slavonije, I952.

2I Povijest oblikovanja namještaja, nastavljajući rad Danice Pinterović, istraživala je i publicirala Ida Horvat. Sveobuhvatni pregled razvoja stolarskog obrta, uz ostale grane umjetničkog obrta, s iscrpnim popisom objavljenih radova objavljen je $u$ : IDA HORVAT, Umjetnički obrt u Osijeku, u: Obrt $i$ obrtnici Osječko-baranjske županije I872.-2007., (ur.) Julijo Martinčić, Dubravka Hackenberger, sv. I, Zagreb-Osijek, 20o9., I95-206. 